\author{
Juhász Márta - Békési Bertold
}

\title{
Pilóta nélküli légijárművek energia forrásai
}

\author{
Juhász, Márta - Békési, Bertold: Energy Resources of Unmanned Aircraft Vehicle
}

Aviation is the quickest and most practical way of locomotion, to which people have been paying attention for thousands of years. Today - on account of air traffic, energy crisis and environmentalism - the power source of the aircraft became a key issue. In addition to flight safety, there is a growing emphasis on environmentally friendly operation. The inefficient burning of fossil fuels comes hand in hand with the significant pollutant emission and noise pollution which bother even those living far from the airports. Nowadays the most important objective of researchers and developers is to create an efficient, clean and quiet airplane, thus as a new idea they attempt to utilize electricity in this form on board the aircraft.

The article presents some various energy resources through some example of unmanned aerial vehicle.

Keywords: UAV, electric power, renewable energy

\section{ÖsSZEFOGLALó}

A helyváltoztatás leggyorsabb és legpraktikusabb formája a repülés, amely évezredek óta foglalkoztatja az embert. Napjainkra kulcsfontosságúvá növekedett - a légi forgalom, az energiaválság, a környezetvédelem együttes hatására - a repülőgépek fedélzetén használt energiaforrás. A repülésbiztonság fontossága mellett manapság egyre nagyobb hangsúlyt kap a környezetbarát üzemeltetés. A fosszilis üzemanyagok alacsony hatásfokú elégetésekor jelentős a káros anyag kibocsátás, nagy a zajterhelés - ami még a repülőterektől távol élőket is zavarja. Ma a kutatók, fejlesztők a leghőbb vágya a hatékony, tiszta, csendes repülőgép megalkotása - ezért mintegy új ötletként a villamos áramot próbálják ebben a formában hasznosítani a repülőgép fedélzetén.

$A z$ írásmű néhány jellemző pilóta nélküli légijármű példáján keresztül mutatja be a különféle energiaforrásokat.

Kulcsszavak:

UAV, elektromos hajtás, megújuló energia

\section{BeVEzetés}

Pilóta nélküli repülőeszközöket (UAV . Unmanned Arial Vehicle) már az 1960-as évek óta alkalmaznak, hiszen kis mérete, egyszerü kezelése, megkönnyíti az egyes területek különböző feladatainak végrehajtását. Szükségességüket szinte minden szakterület alátámasztja; a katonai alkalmazáson túl a katasztrófavédelemi, térképészeti és egyéb polgári körökben is találkozhatunk velük.

A hagyományos repülőgépek repülési ideje sokáig növelhető légi utántöltéssel. Az UAV-k esetében ez nem lehetséges, így más megoldások kerültek előtérbe. Ahhoz, hogy az UAV-k légi és földi rendszerei megfelelő módon működhessenek, elengedhetetlen eszközöket kell alkalmazni és üzemeltetni, sőt legtöbbször a tartalékokra is gondolnunk kell. Erre a legjobb módszer a duplázás (dublírozás), azaz minden eszköz mellé célszerű még egy tartalékot is tervezni. Például ha az adott eszköznek zsúfolt légtérben kell repülnie, vagy nagy értékű rakományt szállít, akkor különösen fontos a légijármű biztonságának növelése. Meghajtásuk sokféle módon lehetséges, de a legkisebb 
ilyen eszközök ezen a területen is akkumulátoros villanymotorral rendelkeznek Az UAV-k esetében az energia tárolásának rendszere hasonló módon lehetséges, mint a nagyobb elődjeiknél: vagy a hajtómű által nyeri az energiát, vagy pedig az APU (Auxilary Power Unit - segédhajtómű ) által, ami egyszerre táplálja, a földön és a levegőben egyaránt a gép elektromos, hidraulikus, és pneumatikus rendszereit. Természetesen a különösen nagy magasságon üzemelő MAV-ok (Micro Air Vehicle) és HALE (High Altitude Long Endurance) UAV-k esetében ez eltérő, hiszen a nagy leterheltség miatt az elektromos energiatárolási képesség hoszszabb kell hogy legyen a normálisnál [3].

\section{NAPELEMES PILÓTA NÉLKÜLI LÉGIJÁRMŰVEK}

Ahhoz, hogy a pilóta nélküli légijárművek energia forrásait elemezzük, fontos, hogy megismerkedjünk néhány típussal (1. táblázat), amelyeken keresztül a későbbiekben bemutatásra kerül a két energiatároló rendszer is. Az első UAV próbálkozások a Sunrise I. és Sunrise II. típusú gépekhez köthetőek a 60-70es évekből. Ezeknél a típusoknál még nagyon kicsi számokról beszélhetünk, inkább a technika kezdetlegességét támasztják alá. A napelemes repülés világrekordját a Solar Impulse döntötte meg 26 órányi repüléssel. A pilóta nélküli repülőgépek kategóriáját viszont egy brit vállalat vezeti, a Qinetiq, jelentősen túlszárnyalva a Solar Impulse rekordját. Zephyr névre keresztelt nagy magasságra tervezett, nagy hatótávolságú pilóta nélküli repülőgépe (HALE UAV- High Altitude Long Endurance) 14 nap 22 percet töltött a levegőben, ezzel bebizonyítva, hogy akár hetekig is biztosítani tudja az elvárt felderítési képességet. A robotrepülőgépek körében korábban a fosszilis meghajtású Northrop Grumman RQ-4 Global Hawk tartotta a levegóben egyhuzamban eltöltött idő rekordját 30 óra 24 perccel, ezt azonban a Zephyr már 2008-ban felülmúlta. A korábbi ember által vezetett napelemes gépek ihlették a Pathfinder megalkotóit. Ez a típus nevéhez hűen úttörőnek számított, hiszen már 1981-ben elkészült a ter- ve, azonban technológiai akadályok miatt egy évtizedet csúszott a megvalósítás. 1994-ben aztán a NASA foglalkozott a géppel az ERAST (Environmental Research Aircraft and Sensor Technology) program keretein belül, melynek célja, hogy a Pathfinder kutatási feladatokat végezzen a sztratoszférában. 1998-ra készült el a továbbfejlesztett változata, a Pathfinder Plus. A sok új technológiai fejlesztés mellett, alapvetően nagyobb a szárnyfesztáv, illetve új nagyobb hatásfokú napelemekkel szerelték fel. A fejlesztések tovább folytatódtak, a következő típus a Centurion nevet viseli, melynél szintén a szárnyfesztáv növelésével foglalkoztak elsősorban, megduplázva a Pathfinder méreteit. A gép meghajtása 14 motorral történik, ami természetesen együtt jár a több, nagyobb teljesítményű napelemekkel. Érdekesség, hogy a gépnek nincs törzse, helyette 5 gondola biztosítja a futóművek helyét, illetve szállítmányok tárolására alkalmasak. A kétezres évek elején került napvilágra a sorozat egyik legkorszerübb darabja a Helios. Repülési csúcsmagasságával új rekordot állított be. Egyedi tervezésű, mivel a szárnyain elhelyezkedő napelemek felülről és alulról megvilágítva is szolgáltatnak energiát. Kitüzött célja volt a 25 órás repülési idő elérése, de 2003-ban váratlanul egy teszt közben az óceánba zuhant, így a terv meghiúsult. Nemrégiben került napvilágra a Puma AE által a legfrissebb ember nélküli elektromos mini napelemes repülőgép. $A$ teszt során 9 órán át sikerült a levegőben maradnia, ami jelentősen hosszabb, mint az eddigi repülések. A rendszerben a legvékonyabb és egyben leghatékonyabb gallium-arzenid film technológia ${ }^{1}$ került alkalmazásra, aminek köszönhetően megnőtt az akkumulátorok múködésének időtartama $[9$, $14,15,20]$.

Az UAV-k esetében rendkívül praktikus az elektromos hajtás, hiszen nincs szükség a repülőgép vezetőre, sem az utasok vagy egyéb sú-

${ }^{1}$ A gallium-arzenid film technika lényege, hogy több rétegben visznek fel egymásra olyan félvezetőket, amik a Napból érkező fény spektrumának más-más részére reagálnak, így nagyobb hányadát hasznosítják. 
1. táblázat Napelemes UAV-k adatai

\begin{tabular}{|l|c|c|c|c|c|c|c|c|}
\hline & $\begin{array}{c}\text { Sunrise } \\
1974\end{array}$ & $\begin{array}{c}\text { Solar } \\
\text { Challenger } \\
1981\end{array}$ & $\begin{array}{c}\text { Pathfinder } \\
\text { plus } \\
1998\end{array}$ & $\begin{array}{c}\text { Centurion } \\
1997\end{array}$ & $\begin{array}{c}\text { Helious } \\
\text { HPO3 } \\
2001\end{array}$ & $\begin{array}{c}\text { Solar } \\
\text { impulse } \\
2009\end{array}$ & $\begin{array}{c}\text { Zephyr } \\
2010\end{array}$ & $\begin{array}{c}\text { Sky } \\
\text { Sailor } \\
2006\end{array}$ \\
\hline teljes tömeg [kg] & 12,24 & 90,71 & 317,51 & 861,82 & 1052,33 & 1587,57 & 53,07 & 5,44 \\
\hline $\begin{array}{l}\text { szárny fesztávol- } \\
\text { ság [m] }\end{array}$ & 9,75 & 14,32 & 36,88 & 62,78 & 75,28 & 63,39 & 22,55 & 3,35 \\
\hline Sebesség [km/h] & 12 & 8,8 & 12,5 & 31 & 31 & 30 & & 144,81 \\
\hline $\begin{array}{l}\text { Maximális telje- } \\
\text { sítmény [kW] }\end{array}$ & 12,48 & 32,18 & $24-29$ & $30-43$ & 69,18 & & 21336 & 500 \\
\hline $\begin{array}{l}\text { Repülési magas- } \\
\text { ság [m] }\end{array}$ & 2438 & 4359 & 24445 & 30480 & 29469 & 11887 & 24 perc & \\
\hline $\begin{array}{l}\text { repülési idótar- } \\
\text { tam } \\
\text { [óra] }\end{array}$ & & & $14-15$ & $15-16$ & 24 & 36 & 336 óra & \\
\hline $\begin{array}{l}\text { hasznos teher } \\
\text { [kg] }\end{array}$ & & & 68,03 & $30-180$ & 329,30 & & 2,26 & \\
\hline
\end{tabular}

Forrás: Szerkesztette Dr. Békési Bertold (MS Word) [12] irodalom alapján

lyokkal számolnunk. Nem utolsó sorban fontos szempont, hogy az emberi élet nincs közvetlen veszélyben.

UAV-khoz leginkább alkalmas a már elérhető szekunder telepek jobb energiasürüséggel és magasabb élettartammal feltöltött állapotban. Egy hosszú élettartamú nagy fajlagos teljesítményű primer akkumulátor telep alkalmas lenne MAV-ok meghajtására is. A dinamikus átalakítási folyamatok, mint például a dízel generátorok vagy turbinák nagy lehetőséget rejtenek az UAV teljesítményszintjének növeléséhez [3].

\section{AZ ENERGIATÁROLÓK}

Ahhoz, hogy a későbbiekben is fel tudjuk használni a meglévő energiát, fontos az energiatároló rendszer alkalmazása. Alapvetően két eszköz áll rendelkezésünkre: az üzemanyagcellák és az akkumulátorok. Utóbbival sokáig inkább csak az ürhajókon találkozhattunk, de manapság már egyre inkább terjed a használata.
Elsőre az akkumulátorok vonzóbbak lehetnek kis méretük és alacsony költségük miatt, de teljesítményük és energiasürűségük jóval kisebb mint a többi alternatívának. Ehhez képest az üzemanyagcellák teljesítménye több száz wattól több száz kilowattig terjedhet. Mivel az üzemanyagcelláknak igen magas a hatásfoka, élettartamuk is megnövekszik. Az üzemanyagcellák repülésben való elterjedéséhez, illetve a magasabb teljesítményszinthez hagyományos dinamikus átalakító rendszerekre (turbinákra, vagy dízel generátorokra) lenne szükség. A hosszú múködési idő és a kisebb terhelés érdekében a napelemes akkumulátor rendszereket lehetne alkalmazni [10].

Az üzemanyagcella egy galvánelem, amely átalakítja az üzemanyag kémiai energiáját elektromos energiává. Lényegesen nagyobb a teljesítménysűrűségük, mint az akkumulátoroké. Az üzemanyagcella esetében az „újratöltés” azonnal megvalósul, amíg a legújabb gyorstöltésű akkumulátorok minimálisan is körülbelül egy órát és külső elektromos áramforrást 
igénylenek az újratöltéshez. Az üzemanyagcellában zajló munka egy katalitikus folyamatként müködik. A leggyakrabban felhasznált üzemanyag a hidrogén. $A$ folyamat menete: a vízbe elektromos áramot vezetnek, aminek hatására a vízmolekulák kötései felbomlanak, azaz hidrogénre és oxigénre válnak szét, majd az alkotók gázhalmazállapotban távoznak. Az üzemanyagcellákban ennek a reakciónak a fordítottját tapasztalhatjuk, azaz az árammal való vízbontás fordítottját. Víz helyett más anyagot is lehet használni, mint például az alkohol, de ebben az esetben már az áram mellett víz és szén-dioxid is felszabadul. A hidrogén alapú üzemanyagcellák előállítása energiaigényes, veszélyes nagy mennyiségben tárolni [1].

Az üzemanyagcella szerkezetileg anódból és katódból áll. Az anódhoz vezetjük a tüzelőanyagot, a katódhoz pedig az oxidáló anyagot. Tartalmaz még a két elektródát elválasztó elektrolitot. Az elektrolitnak kettős feladata van, egyrészt az elektródákat kell egymástól elszigetelnie, hogy a két elektródához juttatott kiindulási anyagok egymással ne érintkezzenek, másrészt ionvezetőnek kell lennie, hogy a kémiai reakció létrejöhessen. A reakció megfelelő sebességének eléréséhez szükséges katalizátor használata. Fontos, hogy olyan anyag legyen, amely úgy gyorsítja fel a reakciót, hogy nem vesz részt benne. A gáz halmazállapotú anyagok hajlamosak a szilárd anyag felületén megkötődni, ami a molekulák szétválasztódásához vezet, így lehetővé teszik más molekulákkal való reakciót. Hidrogén gáz esetén katalizátorként platinát, ródiumot és ruténiumot alkalmaznak $[4,8,10]$.

$\mathrm{Az}$ üzemanyagcellák mobil alkalmazásához a legmegfelelőbb típus a polimer elektrolit membrános cellák (PEMFC - Polymer Electrolyte Membrane Fuel Cell - Proton Exchange Membrane Fuel Cell ). Ennek a típusnak nagy előnye, hogy a többi üzemanyagcellához képest a legtöbb energiát, sokkal jobb ener- giasűrűségi paraméterekkel rendelkezik, illetve jó a hidegindítási képessége is. A PEMFC müködési hőmérséklete 50 és $100{ }^{\circ} \mathrm{C}$ között mozog (átlagosan $80^{\circ} \mathrm{C}$ ), de alapvetően a membrán anyagától függ. Elektrolitként egy protonvezető membránt alkalmaznak, ami hidrogénionokat szállít. Sokoldalúsága alkalmassá teszi a stabil, a mobil és a hordozható rendszerek kiszolgálására $[8,16,18]$.

Az elektród anyaga a cellákban szilárd polimer membrán (vékony műanyag filmréteg), amely a protonokat átereszti, az elektronokat nem. Az anódon a beáramló hidrogén szétesik protonokra és elektronokra. A protonok a membránon keresztül haladnak a katódok felé, amíg az elektronok egy külső áramkörön keresztül áramlanak, eközben pedig elektromos energia keletkezik. Az elektron az oxigénnel és a hidrogén ionokkal egyesül és víz keletkezik. Az üzemanyagcellák előnyei közé sorolható a gyors indítás, a szilárd elektrolitnak köszönhetően pedig nagymértékben csökken a korrózió. A belső égésű motorokhoz képest elméleti hatásfokát elvi termodinamikus határok nem korlátozzák, a belső égésű motorok hatásfokát viszont a carnot ciklus diktálta termodinamikus határok szabják meg. Hátrányai a drága platina katalizátorok, az üzemanyag szennyeződésre való érzékenységük, illetve az alacsony hőmérsékleten való nagy hőveszteségük. Az üzemanyagcella membránja mindig nedves kell, hogy legyen. A gyakorlatban a tüzelőanyag-cellákat sorosan összekapcsolják, így nagyobb kimeneti feszültséget kapnak. A sorba kapcsolt cellák száma függ az elvárt kapocsfeszültségtől, felülete pedig az elvárt áramerősségtől. Egy cella (100 W esetén) terhelés alatti feszültsége $\mathrm{kb} .0,7 \mathrm{~V}$, maximális feszültsége kb. 1,2 V. Kis mérete, és nagy teljesítmény-tömege ideálissá teszi az alkalmazását repülőgépekben. A fő probléma az üzemeléshez szükséges hidrogén szállitása és tárolása [4, 7, 8, 10, 19]. 
A hidrogén üzemanyagcellák belső ellenállása meglehetősen nagy, ezzel szemben az akkumulátorok mégis jobban elviselik a változásokat töltésben, mint az üzemanyagcellák. Az üzemanyagcellákat maximális teljesítményre kell tervezni, ezért nagy és nehéz üzemanyag tárolót igényel kiegészítő egységgel. Mobil alkalmazásnál általában kombinálják az üzemanyagcellákat és az akkumulátorokat. A repülőgépeknél kifejezetten speciális könnyű alkatrészeket szükséges kifejleszteni a működtetéséhez. A hidrogén kriogén cellákban tárolható vagy nagynyomású tartályban, és mivel a folyékony hidrogén nem rendelkezik jó energetikai egyensúllyal, nem alkalmas hosszútávú tárolásra, sűrüsége viszont magasabb, ezért ajánlatos inkább nagynyomású tartályban tárolni. Ahhoz, hogy folyékony formában tudjuk tárolni, drasztikusan le kell hüteni. A hidrogén forráspontja 20 Kelvin vagy -435 F. Emiatt nagyon gyorsan felforr amikor kiömlik, létrehozva egy szűk gyújtási ablakot. Egyébként is komoly hideg sérülést/égést tud okozni, illetve szétfagyasztja az alkatrészeket. Zárt helyiségben normál hőmérsékleten óriási gáznyomást hoz létre széttörve a biztonsági szelep nélküli csöveket [10,19].

Természetesen ezek az eszközök még nem alkalmasak a nagy teljesítményt igénylő repülőeszközök hajtására, de a katonai repülésben a pilóta nélküli robotrepülőgépek energiaszükségletét kielégíthetik, illetve a polgári repülésben a kis teljesítményű repülőgépeken lehetséges a használatuk. Az amerikai Boeing repülőgépgyár volt az első, amely üzemanyagcellás repülőgéppel végrehajtott sikeres repülést. 2008 márciusában, egy Diamond Aircraft Industries
Dimona HK 36 kétszemélyes motoros vitorlázó repülőgépet elektromotorral, üzemanyagcellával, lítium-ion akkumulátorral és protonáteresztő membránnal (PEMFC) láttak el. Ezzel a konstrukcióval 1000 méteres magasságba emelkedtek, majd a további 20 perces vízszintes repüléshez kizárólag az üzemanyagcellát
1. ábra Az üzemanyagcellák müködése

LEVEGÕ

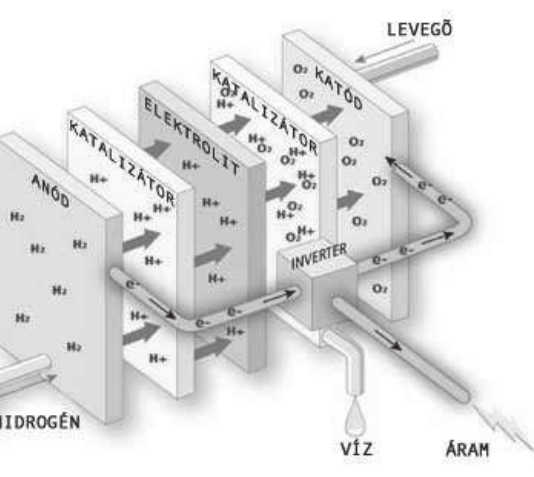

Forrás: [19] irodalom alapján

használták. A Boeing mérnökei szerint amellett, hogy a PEMFC üzemanyagcella a jövőben kisebb méretű pilóta által vezetett vagy pilóta nélküli motoros gépek számára hosszabb repülési időt tehet lehetővé, kilátásba helyezték az utasszállító repülőgépek segédhajtóműveinek kiváltását ezzel a technológiával. Így a segédberendezéseket ellátó jelenleg kerozinnal üzemelő sugárhajtóművek fogyasztása és káros anyag kibocsátása kiküszöbölhető lenne. A fejlesztéseknek jelenleg nem célja a nagy utasszállító repülőgépek fő hajtóműveinek lecserélése, mivel ahhoz a technológia és az energiatárolás területén még nagy előrelépések szükségesek, de a pilóta nélküli repülőeszközökön való alkalmazás praktikusnak tűnik $[6,10]$.

A rendszer előnyei:

- más fosszilis üzemanyag alapú technológiá- 
nál nagyobb hatékonyság;

- könnyen telepíthető;

- legtöbb esetben az üzemanyagcellák káros anyag kibocsátása 0 , vagy nagyon alacsony zajszintű, eltekintve az alkalmi vibrációktól.

Hátrányai:

- magas ár;

- a különleges anyagoknak és bonyolult tervezésnek, összeszerelésnek köszönhetően nagy érzékenység az üzemanyag szennyezettségre, emiatt pedig további ráfordítások szükségesek a szűrőkre és tisztítókra;

- képzett szakszemélyzet szükséges a karbantartáshoz és a javításhoz [10, 19].

A gyakorlatban az üzemanyagcellák osztályozása az alkalmazott elektrolit szerint történik ( 2 . táblázat). hető akkumulátorokat (elsődleges) a reagens lemerülése után ki kell cserélni. Az újratölthető akkumulátorok (másodlagos), teljesen töltött állapotuk helyreállításához egyenáramú forrás szükséges. A nem újratölthető akkumulátoroknak magasabb az energiasürüségük, azonban az újratölthető elemek előnye, hogy alacsony a belső ellenállásuk, így eleget tesz a magas áramigénynek. A lítium alapú akkumulátorok viszonylag alacsony költségük, sürüségük és energiájuk miatt vonzóbbak az elektromos repülőgépek alkalmazásának területén. A lítium-ion akkumulátorok magas energiasűrűsége miatt az átlagosnál nagyobb a kapacitása. Tömege viszonylag kicsi, mérsékelt kisütési áram jellemzi. Időszakos kisütésre nincs szükség, ezért a karbantartása sem igényel túl sok

2. táblázat Üzemanyagcellák osztályozása az alkalmazott elektrolit szerint

\begin{tabular}{|l|c|c|c|}
\hline Alkalmazott elektrolit & Üzemi hőmérséklet & Tüzelőanyag & Rövidítés \\
\hline \multirow{2}{*}{ alkálilúg } & $60-90^{\circ} \mathrm{C}$ & hidrogén & $\begin{array}{l}\text { AFC - AFC: Alkaline Fuel Cell - } \\
\text { Alkáli tüzelőanyag-cella }\end{array}$ \\
\hline \multirow{2}{*}{ ionvezető müanyag } & $20-80^{\circ} \mathrm{C}$ & hidrogén & PEMFC \\
\cline { 2 - 4 } foszforsav & $80-110^{\circ} \mathrm{C}$ & metanol & DMFC \\
\hline alkálisó-oldat & $200{ }^{\circ} \mathrm{C}$ & hidrogén & $\begin{array}{c}\text { Phosphoric Acid Fuel Cell } \\
\text { - Foszforsav-elektrolitos } \\
\text { tüzelőanyag-cella }\end{array}$ \\
\hline ionvezető kerámia & $500-800{ }^{\circ} \mathrm{C}$ & $\begin{array}{c}\text { hidrogén, szén- } \\
\text { monoxid, metán }\end{array}$ & $\begin{array}{l}\text { MCFC: Molten Carbonate Fuel } \\
\text { Cell - Alkáli-karbonát-olvadék- } \\
\text { elektrolitos tüzelőanyag-cella }\end{array}$ \\
\hline
\end{tabular}

Forrás: Szerkesztette Juhász Márta (MS Word) [19] irodalom alapján

Az üzemanyagcellákon kívül a tárolók között népszerübb típus: a savas és lúgos akkumulátor. A folyamat során kémiai energia alakul át villamos energiává, elektrokémiai kisüléseken keresztül. A benne elhelyezkedő cellák (elsődleges és másodlagos) mindegyike tartalmaz pozitív és negatív elektródákat, szigetelő szeparátorlemezeket és elektrolitot. A nem újratölt- időt. Hideg helyen való tárolás esetén az élettartamát 40\%-os töltöttség mellett növeljük. Gyártása meglehetősen költséges, drágább, mint a NiCd gyártása. A technika még nem teljesen kiforrott, mert a fém és a kémiai anyag kombinációjának megváltoztatása befolyásolja az akkumulátor teszt eredményeket, különösen gyorsteszt módszereknél. Védőáramkört 
(Battery Management System) igényel, ami kiegyenlíti a cellák feszültségét. Használata esetén kisebb az esély az elektrolit szivárgásra, mivel a túltöltésre ellenállóbbak. Szállítása egyszerűbb, hátránya viszont a töltőfolyamat érzékenysége, mivel a túlfeszültség olyan kémiai reakciókat indíthat be a cellákban, amelyek tűzveszélyesek. Ennek ellenére a legjobbnak mondható hordozható energiatárolási eszköz a lítium polimer akkumulátor [10].

Az akkumulátorok alapvetően biztonságosak. A lítium-ion akkumulátorok hagyományos fém oxidokat alkalmaznak, amik közelítenek a fajlagos energiájuk elméleti határához. Az akkumulátorgyártó cégek az üzemidő optimalizálása helyett, jelenleg inkább a gyártási módszereket fejlesztik a biztonság megerősítése, illetve az élettartam növelése érdekében.

$\mathrm{Az}$ akkumulátorok tárolása is nagy kihívást jelent. Az adott repülőtérnek biztosítania kell a nagyfeszültségű akkumulátorok oltásához szükséges eszközöket. Tárolása hangárban optimális, természetesen a folyamatos ellenőrzések, illetve a megfelelő tűzvédelmi szabályok betartása mellett [10].

A korábban említett Battery Management System (BMS) védőáramköri rendszerként funkcionál. Ellenőrzi az akkumulátor állapotát, környezetét, adatokat számol, jelenti, majd kiegyensúlyozza azt, tehát megvédi az akkumulátort. Megakadályozza bármely cella biztonságos múködési értékének túllépését. Ezenkívül kiegyenlíti az akkumulátorok töltöttségi állapotát, ezáltal maximalizájla a kapacitást. A BMS múködésbe léphet például túláram, túlfeszültség vagy alacsony feszültség esetén. Az ólomsavas, illetve lítium ion celláknál különösen fontos az alkalmazása [5].

Jelenleg két fő energiatárolási módról beszélhetünk: hidrogén üzemanyagcellák vagy akkumulátorok. Láthatjuk, hogy mindkét megoldásnak megvannak az előnyei és a hátrányai. Az üzemanyagcellákat használó hajtómű egyértelmúen biztonságosabb, viszont igen költséges. Ezen kívül több mozgó mechanikus alkotóelme van, ami csökkenti a rendszer megbízhatóságot. A legtöbb elektromos hajtású üzemanyagcellás repülőgép kiegészítésképpen akkumulátorokat is használ, mert a csak üzemanyagcellát alkalmazó gépek esetén nehezebb az üzemképes megvalósítás, több kockázati tényezőt tartalmaz. Mint azt látjuk az energiatároló rendszer akkumulátorokkal egyszerűbb és könnyebb. Nincs mozgó alkatrész, és mivel több kisebb részből áll, egy cella meghibásodása nem okozza az akkumulátor teljes meghibásodását. A fő probléma a cellák érzékenysége a túlfeszültségre, vagy az intenzív kisülésre, ami a cellák robbanásához vezethet. Hátránya még, hogy nem lehet üríteni, tehát mindenképpen el kell használni [10].

Jelenleg egyedül mikro- és mini UAV-k meghajtását biztositják akkumulátorok és villanymotorok együtt. Habár jelentős fejlődések folyamatosan történnek az akkumulátor tervezésben és gyártásban, nemcsak a motor áramfelvételére, hanem a hasznos teher, és a kommunikációs rendszer igényére is gondolnunk kell. Így az ilyen UAV rendszereknek a repülési hatótávolsága és sebessége, illetve a kommunikációs rendszerük és a hasznos teherrel kapcsolatos képességek korlátozottak. A rendszerek elég kicsik és könynyűek, hogy hátizsákban szállíthatóak legyenek így a nagyon rövidtávú múveletekben, és relative jó körülmények között használhatóak. Tartalék akkumulátorokat is biztosítani kell rendszeres töltéssel, hogy az elektromos táplálás fennálljon. A folyamatos áramellátás más módjai kifejlesztés alatt állnak, hogy megnöveljék az elektromos hajtású rendszerek hatótávolságát és képességeit. Jelenleg is folynak az UAV rendszerekkel kompatibilis napenergiás fotovoltaikus cellák és üzemanyagcellák követelményeinek kialakítása. Mindkét rendszer repült már UAV-val, de jelenleg ennek a technológiának a korai időszakában vagyunk $[3,13,17]$. 
Ma már létezik kifejezetten kisméretű elektromos UAV-k számára kifejlesztett ultrakönynyű üzemanyagcellás energiatároló rendszer is, amely megnöveli a repülés hatótávolságát. Ez pedig az Aeropak. Újszerűsége abban rejlik, hogy a felhasznált üzemanyag repülés

\section{ÖSSZEFOGLALÁS}

A pilóta nélküli repülőeszközök alkalmazása hasznosnak bizonyul, hiszen nem veszélyezteti közvetlenül az emberi életet, és mivel a kezelőszemélyzet váltása egyszerúen megoldható, gyakorlatilag

\section{2. ábra: Aeropak rendszer}

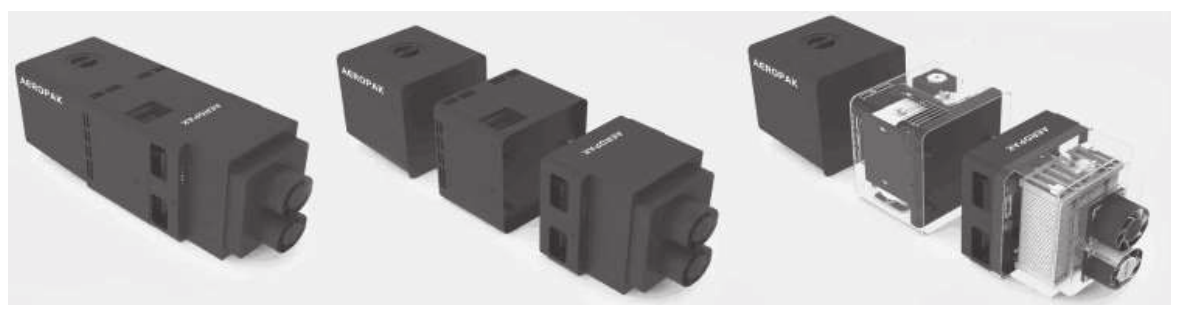

Forrás: [11] irodalom alapján

közben távozik, ezáltal a repülési útvonal során csökkenti a gép súlyát. Erre a fedélzeten egy cserélhető tárolóban elhelyezett hidrogén ellátó rendszert használ. Az Aeropak előnyei:

- a sűrített hidrogént használó rendszerekhez képest feleakkora a térfogatigény;

- nagy energiasűrűség (akár $650 \mathrm{Wh} / \mathrm{kg}$ );

- skálázható előre beállított időtartamokra;

- hibrid alkalmazás akkumulátorral csúcsteljesítmény eléréséhez (felszállás, emelkedés, gyorsítás);

- névleges teljesítmény, csúcsteljesítmény számításával.

- nem gyúlékony kémiai üzemanyag [2, 11]. korlátlan repülési időt érhetnénk el. Az elektromos energiatároló rendszerek használta akkor fontos, ha az energiát villamos áram formájában akarjuk hasznosítani. Erre a legoptimálisabb repülőeszköz az UAV, hiszen nem kell számolunk további súlyokkal és térfogattal, mint a hagyományos repülés területén. A pilóta nélküli repülőeszközök esetében az energiatárolás legmegfelelőbb eszköze az Aeropak rendszere. Gyártása már folyamatban van az 5-12 kg és a 12-80 kg kategóriájú UAV-khoz. Ezzel a forradalmi konstrukcióval a felsorolt előnyöknek köszönhetően egy egészen nagyszerű technikai újitás van születőben, ami a későbbiekben akár az utasszállítást is gazdaságosabbá és energiatakarékosabbá teheti.

Felhasznált irodalom

[1.] A hidrogén üzemanyagcellák müködése url: http://www.alternativenergia.hu/wp-content/themes/ alternativenergia/tudjmegtobbet.php?catid=20\#63 (2013.09.01.)

[2.] Aeropak Technical data sheet url: http://www.hes.sg/files/AEROPAK_Technical_Data_Sheet.pdf (2013.10.01.)

[3.] Békési Bertold, Wührl Tibor: Redundancy for micro uavs - control and energy system redundancy Deterioration, Dependability, Diagnostics 2012, Brno, University of Defence, 2012. pp. 123-130. (ISBN:978-80-7231-886-5) (2013.10.02.) 
[4.] Berkes Balázs, Platina vizsgálata tüzelőanyagcellák katalitikus folyamatainak modellezéséhez url: http:// www.fuelcell.hu/downloads/recomend/BBB_tdk.pdf (2013.08.26.)

[5.] BMS url:http://liionbms.com/php/white_papers.php (2013.08.21.)

[6.] Boeing Flies First Ever Battery Fuel Cell Plane! url: http://inhabitat.com/transportation-tuesday-boeingflies-first-fuel-cell-plane/ (2013.09.18.)

[7.] Első repülés üzemanyagcellákkal url: http://www.mernokbazis.hu/cikkek/elso-repulesuzemanyagcellakkal (2013.09.03.)

[8.] Fuel Cells url: http://www.fuelcells.org/ (2013.08.30.)

[9.] History of Solar flight url: http://www.asl.ethz.ch/research/asl/skysailor/History_of_Solar_Flight.pdf (2013.08.30.)

[10.] Ing. Miroslav Šplíchal, Ph.D.- Mgr. Jaromír Hammer, Safety aspect of electric powered New Trends in Civil Aviation 2013, 93. oldal

[11.] Long Endurance Battery Alternatives for Electric UAS-Aeropak 1 url: http://resources.arcolaenergy. com/docs/Brochures/AEROPAKBrochure.pdf (2013.09.26.)

[12.] Manish R. Bhatt [2012]: Solar power unmanned aerial vehicle: high altitude long endurance applications (hale-spuav). The Faculty of the Department of Mechanical and Aerospace Engineering San Jose State University. page 57-58.

[13.] Molnár András: Elektromos hajtású robotrepülőgépek url: http://portal.zmne.hu/download/bjkmk/ bsz/bszemle/kulon0202.html (2013.08.21.)

[14.] Pathfinder Plus url: http://www.avinc.com/uas/adc/pathfinder_plus/ (2013.08.28.)

[15.] Pathfinder url: http://www.avinc.com/uas/adc/pathfinder/ (2013.08.28.)

[16.] Protoncsere Membrános Cella url: http://www.fuelcell.hu/index.php/hu/tuezelanyag-elemek/pemfc (2013.09.15.)

[17.] Reg Austin, Aeronautical Consultant, Unmanned aircraft system UAVs design, development and deployment;105-106, 291-293. oldal url: http://rahauav.com/Library/Unmanned\%20Vehicles/ Unmanned-Air-Systems(www.RahaUAV.com).pdf (2013.09.26.)

[18.] Új generációjú üzemanyagcellák url: http://epa.oszk.hu/00700/00775/00049/1564-1569.html (2013.09.25.)

[19.] Üzemanyagcellák url: http://www.foek.hu/korkep/enhat/uzemanyagcella/uzemanyagcella.html (2013.08.30.)

[20.] Zephyr Solar-Powered HALE UAV, United Kingdom url: http://www.airforce-technology.com/projects/ zephyr/ (2013.09.03.) 